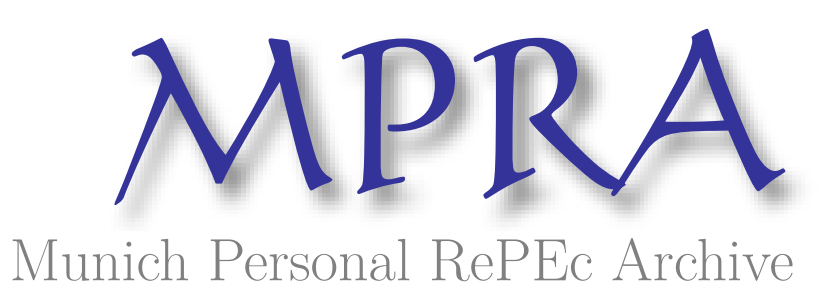

\title{
The US monetary performance prior to the 2008 crisis
}

Li, Kui-Wai

2012

Online at https://mpra.ub.uni-muenchen.de/41036/

MPRA Paper No. 41036, posted 05 Sep 2012 13:58 UTC 
Applied Economics, 45 (24), 2013: 3449-3460

The U.S. Monetary Performance Prior to the 2008 Crisis

Kui-Wai Li

\begin{abstract}
This article uses a structural VAR approach to study the different shocks to the monetary performance in the two decades of the U.S. economy prior to the 2008 financial crisis. By using the Federal Fund Rate as a measure of change in monetary policy, the study shows that interest rate expectation is informative about the future movement of Federal Fund Rate and the anticipated monetary policy should be one of the crucial reasons in causing monetary and financial deterioration in the U.S. economy. The article discusses a possible conjecture of a low interest rate trap when a persistent and prolonged low interest rate regime led to financial instability.
\end{abstract}

JEL classification: C32; E52; O51.

Keywords: Monetary shocks; Interest rate; Financial crisis.

Kui-Wai Li, Department of Economics and Finance, City University of Hong Kong. Tel.: 852-3442 8805; fax: 852-3442 0195; E-mail address: efkwli@ cityu.edu.hk

Acknowledgement: Research funding from the City University of Hong Kong in the form of Strategic Research Grant (Grant number: 7008129) is gratefully acknowledged. The author is thankful to Mark Taylor, Sven Arndt, Alan W. K. Wong and anonymous reviewers for their comments and research assistance from Douglas K. T. Wong and Siyang Ye. The usual disclaimer applies. 
I Introduction

Since banks and hedge funds have invested heavily in subprime mortgage backed securities, few have predicted that the U.S. subprime mortgage industry could lead to a worldwide credit crunch when the Fed takeover the two mortgage-based security companies and the closure of Lehman Brothers. Efforts have been made to rescue the subsequent economic collapses (Financial Services Authority, 2009; French et al., 2010; IMF, 2009). The 2008 crisis has raised the relevance of monetary fundamentals (Taylor and Williams, 2009; Taylor, 2009). Schwartz (2009) explained that expansive monetary policy, flawed financial innovations and collapse of trading contributed to the 2008 financial crisis.

Studies on the U.S. monetary economy have identified five monetary features under Alan Greenspan's chairmanship (7/1985 to 8/2005) of the U.S. Federal Reserve. The practice of a direction-known interest-rate smoothing policy showed a stepwise interest rate trend. It has the advantage of financial stability and certainty, but since it could be anticipated, the Fed could not respond swiftly to shocks, and the resulting inflation variability might have introduced instability and volatility (Bullard and Mitra, 2007; Caplin and Leahy, 1996; Goodhart, 1996; Cecchetti, 1996). The Fed practiced inflation-targeting and an open acknowledgement for low long-run inflation (Mankiw, 2002; Blinder and Reis, 2005; Goodfriend, 2005; Bernanke and Mishkin, 1997). Monetary discretions made without pre-commitment to future course of action had resulted in uncertainty and time-inconsistency (Kydland and Prescott, 1977; Fischer, 1990; Barro and Gordon, 1983; Bryant et al., 1993, McCallum, 1988). The adoption of the Taylor rule called for changes in the Federal Fund Rate in response to changes in the price level, although there were periods of deviation (Taylor, 1993; Yellen, 2004; Mehra and Minton, 2007; Blinder and Reis, 2005; Woodford, 2001). The personalization of monetary policy (Greenspan put) has led to a belief that stock markets would be saved when it went down but would not intervene to stop it from rising (Miller et al., 2002).

This article examines the monetary fundamentals of the U.S. economy in the two decades leading up to the 2008 financial crisis. The monthly U.S. data are obtained from the DataStream and International Financial Statistics (IFS) for the sample period between 1989.1 and 2008.7 prior to financial crisis in September. A structural VAR approach is used to study monetary shocks in the two decades of the U.S. economy. Section II examines the monetary performance and conjectures a "low interest rate trap" that arises from the prolonged low interest rate regime. 
Section III and IV present the empirical methodology and the empirical findings, respectively. Section V concludes.

\section{Monetary Performance and Conjecture}

Figure 1 shows the performance of ten U.S. variables prior to the 2008 financial crisis. Real GDP and real investment show the level of economic activities. The monthly real GDP and real investment data are constructed from quarterly data by the state space approach with the monthly industrial production data serving as the interpolator variable, assuming that the interpolation is describable as an $\mathrm{AR}(1)$ process. The U.S. recession in the mid-1980s has resulted in prolonged economic weakness with a fall in real GDP and real investment until 1992.

The nominal economic variables include S\&P500 and home mortgages; they both were bullish and increased continuously to a historical high level until early 2008. For example, the Nasdaq Composite Index lost half of its points between March and December, 2000, and declined further after the 2001 terrorist attack. In the real estate market, the 1995 Community Reinvestment Act was reformed, while the 1997 Taxpayer Relief Act exempted tax from profits made from sales of residences up to US\$0.5 million for married couples. Home ownership peaked in 2004, but signs on the end of the housing boom appeared in 2005. In early 2007, the problem of subprime mortgage surfaced with Bear Stern closed one of its funds.

While the core Consumer Price Index (CPI) excludes the price influence of food and energy, the drastic increase in the world price of oil (OPW) has affected the U.S. economy. The inclusion of OPW ensures that the estimation model will not suffer from the 'price puzzle' problem (Sims, 1992, Sims et al., 1996; Christiano et al., 1996). The core CPI has increased continuously, and followed closely the OPW trend. The OPW has shown a steady trend in the 1990s, but has increased rapidly since 1999.

The fourth chart shows the Federal Fund Rate (FFR) and the nominal exchange rate (EX) of the U.S. dollar against the British pound is used as the unit of measure in capital flows. A sustained upward movement in EX since 2002 showed that there was capital outflow due probably to the historical low level of FFR. The two indicators of consumer confidence index in 12-month interest rate higher (RH) and 12-month interest rate same (RS) are used as measures on consumer behavior and the dynamic response of the economy to shocks in interest rate expectation. These two variables tend to move in the opposite direction, though the former has 
remained high at different time periods, and has fluctuated more than the latter. The interest rate expectation of consumers is highly volatile at around 35\% to 75\% from 1989 to 1993, when investors did not seem to have definite expectation on the future interest rate.

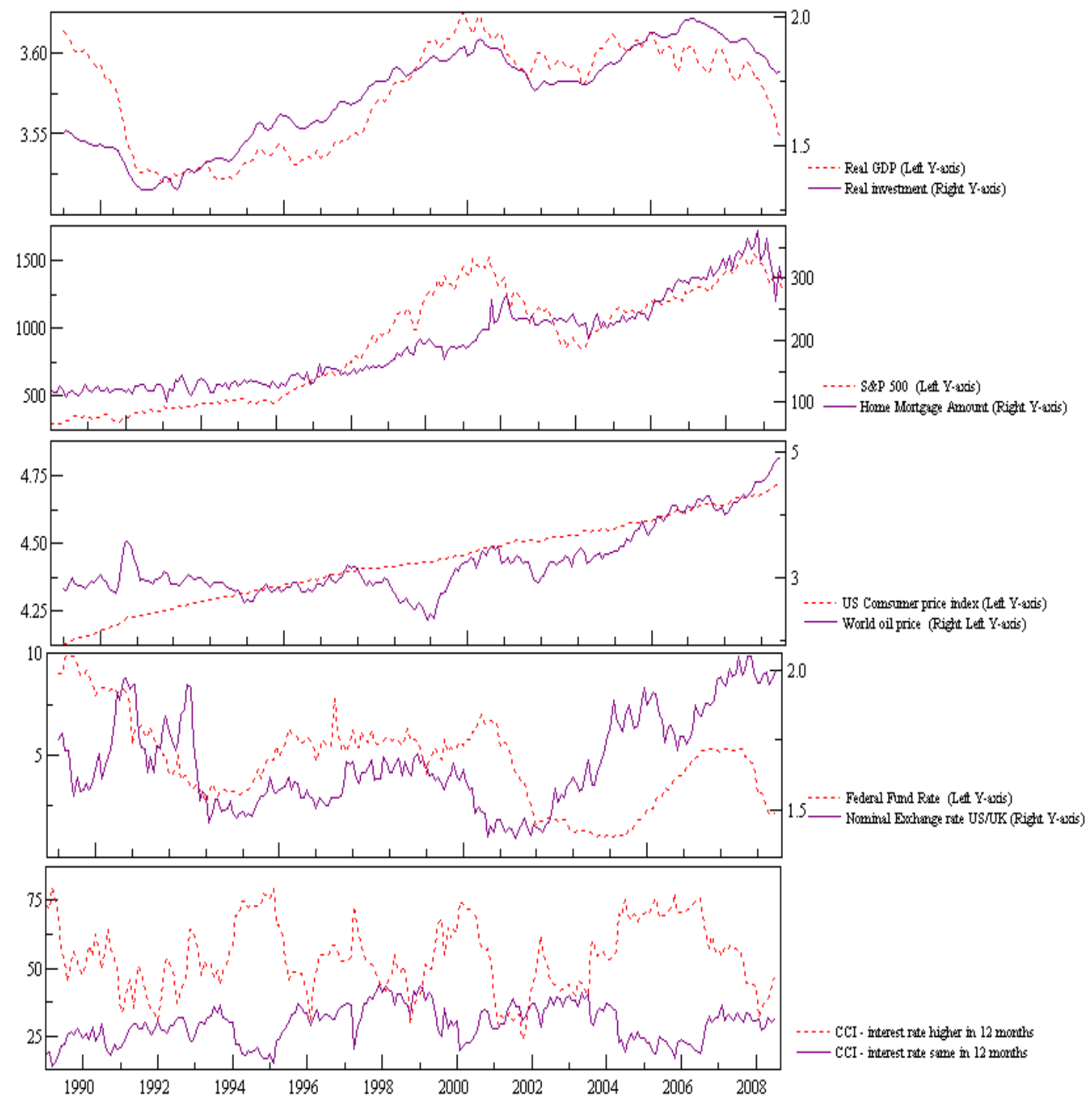

Figure 1 Log U.S. Variables

The FFR trend shows two prolonged low interest rate periods (1993-1995 and 20022004), with a clear downward movement in 1989-1994 when it was lowered from $6 \%$ to $1.75 \%$ in 2001. Economic recovery that began in 1992 suggested that the low interest rate policy could have stimulated the U.S. economy. After the dotcom bubble in March 2000, the Fed took 11 
steps to lower interest rates. Changes in interest rate expectations often occurred in months ahead of the FFR movement, implying a full anticipation of the monetary policy by investors. Starting from 2004, the adjustment on the FFR was not effective in controlling the overheated real estate market. The increase in the FFR from $1 \%$ to $1.25 \%$ on June 30, 2004, brought a two-year upward trend. This could be due to the full anticipation by investors, as high interest rate expectations remained steady between 2004 and 2006, though one could interpret that the low FFR between 2002 and 2004 have stimulated investment, and continued to impact output till 2006.

Once investors' prediction on monetary policy became more accurate over time, interest rate movements might become ineffective in stabilizing business cycles and promoting long-term growth. The monetary conjecture in Figure 2 stylizes the steps and responses in Greenspan's interest-rate policy. When the interest rate fell (arrow "a") and if investors could fully anticipate the next round of interest rate movements, investors would have waited till the interest rate has fallen to its lowest possible level. The initial fall in the interest rate might not lead to much economic adjustment (Lucas, 1981; Sargent and Wallace, 1975; Modigliani, 1977; Barro, 1976). As such, policymakers might think that a further drop in interest rates was needed in order to stimulate investment. It was probable that when the interest rate had reached a very low level, "b", investors would then borrow extensively. The extremely low interest rate now would encourage unproductive, low-return and speculative bubble-prone varieties.

The rapid increase in investment at the low interest rate could produce overheating that called for policy reversal (arrow "c"). The initial reversal in interest rates could even lead to a rise in investment as investors expected higher future borrowing cost. The rise in interest rate would soon lower economic activities. Those who have borrowed at the lowest interest rate at "b" would now face a repayment problem. By the time the interest rate reached a high level, "d", economic slowdown emerged and the authority would then have to revise the interest rate downward, producing another round of stepwise downward movement in interest rate policy (arrow a', b' and c').

When investors could fully anticipate the interest rate movements, fragile investors would wait until interest rate reached the lowest possible level. For example, home ownership was encouraged during the second term of the Clinton administration. As property prices rise the demand for property also rises as home buyers now feared that property prices would soon rise further. Home buyers without full financial credibility were prepared to hedge against the 
expected rising property price. The monetary conjecture in Figure 2 shows that the economy could have been "trapped" at the lowest interest rate levels at points b and b', as investors have got used to the low interest rate and monetary authority found it difficult to maintain a higher level of interest rate. A prolonged low interest rate regime could have encouraged financial and property speculations that cumulated to form the roots of a financial bubble. A stepwise interest rate smoothing policy could eventually produce an unsustainable and cyclical form of monetary policy that helped more to fuel financial instability than to build up sustainable economic capacity. The economy was effectively addicted to a low interest rate regime, making financial resources cheap and promoting low-productivity. While the Fed attempted to manage the business cycle, the interest rate policy could have led to a trade-off in sustainable long-run growth.

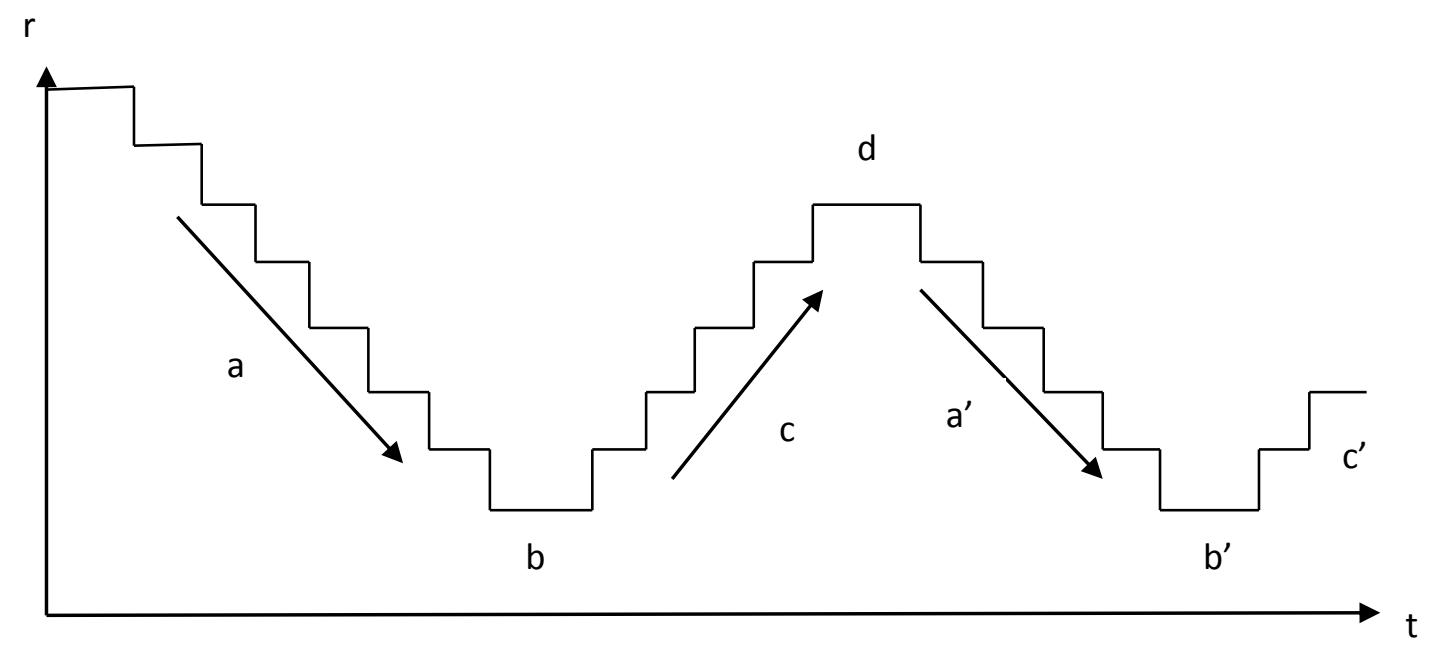

Figure 2 Conjecture of a Low Interest Rate Trap

III Model Identification

The "low interest rate trap" can be studied using U.S. data to show if interest rate followed a stepwise movement and investors anticipated fully its movement. A structural vector autoregressive (SVAR) model (Sims and Zha, 2006; Kim and Roubini, 2000) is used to incorporate the interest rate expectation of investors to show that monetary policy could become ineffective and/or would promote speculation when it is fully anticipated.

The following SVAR system expresses the contemporaneous interactions between the variables in structural form: 


$$
B(L) Y_{t}=\gamma_{0}+e_{t},
$$

where $B(L)$ is a $n \times n$ matrix polynomial in the lag operator, $L ; Y_{t}$ is a $n \times 1$ vector of variables, and $e_{t}$ is a $n \times 1$ vector structural disturbances which is identical independent normal with var $\left(e_{t}\right)$ $=\Lambda$. The $\Lambda$ is a diagonal matrix and the diagonal elements are the variances of structural disturbances such that each structural disturbance can be assigned explicitly to particular equations. Let $B_{0}$ be the contemporaneous coefficient matrix on $L^{0}$ in the structural form, and let $B^{0}(L)$ be the coefficient matrix in $B(L)$ without contemporaneous coefficient $B_{0}$. The matrix polynomial in the lag operator, $L$, is expressed as:

$$
B(L)=B_{0}+B^{0}(L) \text {. }
$$

Consider the reduced form VAR equation:

$$
Y_{t}=\alpha_{0}+A(L) Y_{t}+u_{t}
$$

where $A(L)$ is a matrix polynomial in lag operator, $L$, and $\mu_{t}$ is a vector of reduced-form disturbances with no structural interpretation. Multiply $B_{0}^{-1}$ to the structural form equation:

$$
Y_{t}=B_{0}^{-1} \gamma_{0}+B_{0}^{-1} B(L) Y_{t-1}+B_{0}^{-1} e_{t}=\alpha_{0}+A(L) Y_{t-1}+u_{t} .
$$

The parameters of reduced form VAR equation are related to the parameters of the SVAR equation:

$$
A(L)=B_{0}^{-1} B^{0}(L) .
$$

The reduced form residuals are related to the structural disturbances:

$$
u_{t}=B_{0}^{-1} e_{t}
$$

and its covariance matrix is:

$$
E\left(u_{t} u_{t}^{\prime}\right)=\Sigma=B_{0}^{-1} \Lambda B_{0}^{-1^{\prime}}
$$

The reduced form residuals become the linear combinations of the structural disturbances. Equation (7) suggests that the covariance matrix of the reduced form residuals is not diagonal, and the right hand side of the equation has $n \times(n+1)$ free parameters to be estimated. Since $\Sigma$ contains $n \times(n+1) / 2$ parameters, the parameters in the SVAR equation cannot be identified without restriction. To achieve identification, $n \times(n+1) / 2$ restrictions are needed. By normalizing the diagonal elements in $B_{0}$ to unity, the identification requires at least $n \times(n-1) / 2$ restrictions on $B_{0}$. A non-recursive SVAR system is used to identify the monetary 
policy and interest rate expectation shocks and to estimate their effect on output variables. A number of zero (exclusion) restrictions are imposed on the contemporaneous structural parameters, $B_{0}$, in Equation (6). The following equations show the identification restrictions:

$$
\left[\begin{array}{l}
e_{O P W, t} \\
e_{Y, t} \\
e_{C P I, t} \\
e_{F F R, t} \\
e_{R H, t} \\
e_{E X, t}
\end{array}\right]=\left(\begin{array}{cccccc}
1 & 0 & 0 & 0 & 0 & 0 \\
b_{21} & 1 & 0 & 0 & 0 & 0 \\
b_{31} & b_{32} & 1 & 0 & 0 & 0 \\
b_{41} & 0 & 0 & 1 & 0 & b_{46} \\
b_{51} & b_{52} & b_{53} & b_{54} & 1 & 0 \\
b_{61} & b_{62} & b_{63} & b_{64} & b_{65} & 1
\end{array}\right)\left[\begin{array}{l}
u_{O P W, t} \\
u_{Y, t} \\
u_{C P I, t} \\
u_{F F R, t} \\
u_{R H, t} \\
u_{E X, t}
\end{array}\right] .
$$

The terms on the LHS of Equation (8) show the six sub-equations in the structural model represent the unobserved structural shocks, while $u_{i, t}$ are the observed residuals obtained from the reduced form of VAR analysis. As oil is imported to the U.S. economy, the first sub-equation assumes that OPW is exogenous to the U.S. economy. The second output sub-equation shows that output responds mainly to OPW shocks. However, it also assumed that CPI, FFR, RH and EX impact on the lag values of output. In order to incorporate the influence of real investment, S\&P500 and home mortgages, Equation (8) will be tested in three alternative models with real investment, S\&P500 and home mortgages subsequently replacing output in the second subequation. The output, S\&P500 and real investment are considered as the dependent variable in each model, and their fluctuation depended on OPW, CPI and so on.

The third sub-equation shows the response of CPI with respect only to output and OPW shocks. In the S\&P500 model identification in the second sub-equation, it is assumed that the movement of the S\&P500 index return would not result in contemporaneous price level fluctuation. The coefficient estimate of $b_{32}$ would become zero. We further assume that the S\&P500 index return will contemporaneously respond to the FFR and EX shocks (Ehrmann and Fratzcher, 2004). A negative relationship between exchange rate and stock return would produce a non-zero coefficient estimate for $b_{24}$ and $b_{26}$ (Solnik, 1987; Wong and Li, 2010).

The fourth sub-equation is a monetary policy feedback equation, as the Fed adjusted FFR in response to the OPW and EX. The monetary policy function does not response to output and CPI contemporaneously as it experienced information delays (Sims and Zha, 2006). But investors would utilize all market information and would not be subjected to policy delay. The 
fifth sub-equation represents the interest rate expectation function which is assumed to respond contemporaneously to all variables except EX, as short term EX fluctuation would not affect investors' expectation on interest rate. Lastly, the exchange rate equation is assumed to be related to all variables in the system of equations.

Table 1 Marginal significance level of monetary indicators and consumer confidence indices

\begin{tabular}{lcccccc}
\hline Sample Period & \multicolumn{2}{c}{$1989: 1-1999: 9$} & \multicolumn{2}{c}{$2000: 1-2008: 7$} & \multicolumn{2}{c}{$1989: 1-2008: 7$} \\
\hline Panel A: Forecasted variable & M2 & FFR & M2 & FFR & M2 & FFR \\
\hline Real GDP & 0.776 & 0.788 & 0.698 & 0.266 & 0.863 & 0.787 \\
Real Investment & 0.296 & 0.876 & 0.093 & 0.016 & 0.082 & 0.097 \\
S\&P500 & 0.750 & 0.956 & 0.880 & 0.468 & 0.937 & 0.698 \\
Home Mortgages & 0.294 & 0.714 & 0.464 & 0.128 & 0.591 & 0.002 \\
\hline Panel B: Forecasted variable & & RH & RS & RL \\
FFR (1989:1-1999:9) & & 0.071 & & 0.425 & 0.019 \\
FFR (2000:1-2008:7) & & 0.043 & & 0.767 & 0.277 \\
FFR (1989:1-2008:7) & & 0.213 & & 0.494 & 0.254
\end{tabular}

Notes: For each row of the forecasted variable, the estimated value represents the marginal significance level for omitting six lags of M2 or FFR from an unrestricted OLS equation which included a constant, trend, six lags of price level, and six lags of the forecasted variable. RH, (RS) and [RL] correspond to consumer confidence index - interest rate higher, (same) and [lower] in 12 months. The estimated values in Panel B represent the marginal significance level for omitting six lags of RH, RS or RL from an unrestricted OLS equation that included a constant, trend, and six lags of the forecasted variable.

The two sub-sample periods (1989:1-1999:9 and 2000:1-2008:7) used in the analysis of the September 2008 crisis reflected the dotcom bubble, change of U.S. leadership in 2000 and 2001 terrorist attack. Data are expressed in logarithm and first-difference-stationary verified by the Augmented Dickey-Fuller (ADF) test. The Granger-causality test is conducted to select whether M2 or FFR is appropriate for our analysis (Bernanke and Blinder, 1992; Sims and Zha, 1994). Table 1 Panel A shows the marginal significance level that the lags of either M2 or FFR should be excluded from the equation. Given that smaller estimates are preferred, FFR is superior to M2 in the second sub-sample period but not in the first sub-sample period. For the whole sample period, FFR outperformed M2 as a preferred variable in forecasting other variables. In forecasting the FFR, Panel B reports the marginal significance levels of consumer confidence index on higher (RH), same (RS) or lower (RL) interest rate in 12 months. Among the three different periods, RH performs better in the second sub-sample period and the whole sample 
period, as seen from the smaller value of the estimates. The level of statistical significance for $\mathrm{RH}$ in the first and second sub-sample periods is 10 percent and 5 percent, respectively. RH has shown a higher predictive power in the second sub-sample period than in the first sub-sample period. FFR is used as a monetary policy indicator while RH is the interest rate expectation indicator in the estimation.

\section{Empirical Results}

We examine from Equation (8) the influence of FFR and RH on output, investment, S\&P500 and home mortgages over the two sub-sample periods. The number of lag length in each model is based on the Akaike information criterion. The constant and trend variables are included. Table 2 reports the Likelihood Ratio Test results for over-identification restriction, and that output, investment and home mortgages are over-identified, while S\&P500 is just-identified. The $p$-value corresponds to the hypothesis test of the single over-identification restriction, and a coefficient greater than 0.05 indicates that the particular model cannot be rejected at the 5 percent significance level. Despite the over-identification in some variables that poses unknown problems, one can still estimate the matrix presented in Equation (8).

Table 2: Likelihood Ratio Test for Over-Identification

\begin{tabular}{lcc}
\hline & $\chi^{2}$ & $p$-value. \\
\hline 1989:1 - 1999:9 & & \\
\hline Real GDP & 0.638 & 0.424 \\
Real Investment & 0.271 & 0.603 \\
S\&P500 & $J I$ & $J I$ \\
Home Mortgages & 0.052 & 0.820 \\
\hline 2000:1 - 2008:7 & & \\
Real GDP & 1.015 & 0.314 \\
Real Investment & 0.241 & 0.623 \\
S\&P500 & $J I$ & $J I$ \\
Home Mortgages & 0.424 & 0.515 \\
\hline No: $J$ reses & &
\end{tabular}

Note: $J I$ represents just-identified. 
Table 3: Contemporaneous Coefficients in Structural Models

\begin{tabular}{|c|c|c|c|c|c|c|c|c|}
\hline & \multicolumn{2}{|c|}{ Real GDP } & \multicolumn{2}{|c|}{ Real Investment } & \multicolumn{2}{|c|}{ S\&P 500} & \multicolumn{2}{|c|}{ Home Mortgage Amount } \\
\hline & 1989-1999 & 2000-2008 & 1989-1999 & 2000-2008 & 1989-1999 & 2000-2008 & 1989-1999 & 2000-2008 \\
\hline \multirow[t]{2}{*}{$\overline{b_{21}}$} & 0.000 & 0.000 & 0.011 & 0.010 & 0.023 & -0.080 & 0.218 & 0.020 \\
\hline & $(0.000)$ & $(0.000)$ & $(0.007)$ & $(0.008)$ & $(0.113)$ & $(0.231)$ & $(0.061)$ & $(0.049)$ \\
\hline \multirow[t]{2}{*}{$b_{24}$} & - & - & - & - & 0.115 & -0.510 & - & - \\
\hline & - & - & - & - & $(0.379)$ & (1.593) & - & - \\
\hline \multirow[t]{2}{*}{$b_{26}$} & - & - & - & - & 0.582 & -1.576 & - & - \\
\hline & - & - & - & - & $(1.267)$ & $(5.836)$ & - & - \\
\hline \multirow[t]{2}{*}{$b_{31}$} & -0.009 & -0.021 & -0.009 & -0.021 & -0.009 & -0.021 & -0.008 & -0.021 \\
\hline & $(0.002)$ & $(0.003)$ & $(0.002)$ & $(0.003)$ & $(0.002)$ & $(0.003)$ & $(0.002)$ & $(0.003)$ \\
\hline \multirow[t]{2}{*}{$b_{32}$} & 0.209 & -0.221 & 0.045 & 0.067 & - & - & 0.003 & -0.008 \\
\hline & $(0.629)$ & (1.169) & $(0.023)$ & $(0.033)$ & - & - & $(0.003)$ & $(0.005)$ \\
\hline \multirow[t]{2}{*}{$b_{41}$} & -0.050 & 0.230 & -0.298 & -0.049 & -0.090 & -0.213 & -0.149 & -0.169 \\
\hline & $(0.432)$ & $(0.243)$ & $(0.205)$ & $(0.126)$ & $(0.267)$ & $(0.831)$ & $(0.106)$ & $(0.374)$ \\
\hline \multirow[t]{2}{*}{$b_{46}$} & 12.423 & 6.382 & 4.872 & 0.641 & -2.596 & -5.522 & -0.328 & -7.166 \\
\hline & $(42.915)$ & (3.619) & (3.621) & (1.324) & (6.742) & $(22.122)$ & (1.585) & (9.560) \\
\hline \multirow[t]{2}{*}{$b_{51}$} & -0.120 & 0.000 & -0.333 & -0.066 & -0.067 & -0.010 & -0.197 & -0.095 \\
\hline & (0.349) & $(0.124)$ & $(0.188)$ & $(0.131)$ & $(0.374)$ & $(0.213)$ & $(0.159)$ & $(0.121)$ \\
\hline \multirow[t]{2}{*}{$b_{52}$} & 13.469 & 66.201 & -5.850 & -4.807 & 1.077 & -1.005 & 0.136 & 0.278 \\
\hline & (332.256) & $(50.998)$ & (2.579) & (1.300) & (2.573) & (2.633) & $(0.198)$ & $(0.202)$ \\
\hline \multirow[t]{2}{*}{$b_{53}$} & -17.748 & -4.672 & -8.753 & -8.510 & -6.627 & -4.885 & -2.529 & -4.699 \\
\hline & $(58.780)$ & (3.738) & (7.501) & (3.822) & (8.184) & (5.283) & (6.768) & (3.492) \\
\hline \multirow[t]{2}{*}{$b_{54}$} & 1.781 & 0.048 & 0.549 & 0.044 & -0.555 & -0.150 & -0.200 & -0.150 \\
\hline & $(12.281)$ & $(0.162)$ & $(0.529)$ & (0.089) & (1.107) & $(0.672)$ & (0.224) & $(0.279)$ \\
\hline \multirow[t]{2}{*}{$b_{61}$} & -0.165 & -0.001 & 0.017 & 0.004 & -0.150 & -0.167 & -0.069 & 0.109 \\
\hline & $(0.534)$ & $(0.047)$ & $(0.066)$ & (0.034) & $(0.233)$ & (1.130) & $(0.045)$ & $(0.135)$ \\
\hline \multirow[t]{2}{*}{$b_{62}$} & 81.327 & 88.150 & 1.338 & 1.249 & -0.304 & 2.918 & -0.078 & 0.232 \\
\hline & (183.497) & $(27.467)$ & $(0.838)$ & $(0.362)$ & (1.245) & (15.105) & $(0.046)$ & $(0.369)$ \\
\hline \multirow[t]{2}{*}{$b_{63}$} & -3.991 & 1.424 & -0.031 & 1.829 & 1.053 & 3.773 & 0.602 & -2.177 \\
\hline & $(38.640)$ & (1.434) & (2.985) & (1.016) & $(2.241)$ & (15.125) & (1.554) & $(4.252)$ \\
\hline \multirow[t]{2}{*}{$b_{64}$} & -0.907 & -0.363 & -0.456 & -0.061 & 0.225 & 0.734 & 0.036 & 0.579 \\
\hline & (1.328) & $(0.123)$ & $(0.258)$ & $(0.068)$ & $(0.491)$ & (4.127) & $(0.162)$ & $(0.963)$ \\
\hline \multirow[t]{2}{*}{$b_{65}$} & 0.920 & 0.064 & 0.199 & -0.021 & 0.163 & 0.236 & 0.061 & 0.074 \\
\hline & (3.446) & & $(0.186)$ & & & & & \\
\hline
\end{tabular}

Note: The numbers in brackets are standard errors. 
Table 4 Variance Decomposition of Real GDP, Real Investment, S\&P 500 and Home Mortgages

\begin{tabular}{|c|c|c|c|c|c|c|c|c|c|c|}
\hline & \multicolumn{2}{|c|}{ Shock $1\left(e_{O P W}\right)$} & \multicolumn{2}{|c|}{ Shock $3\left(e_{C P I}\right)$} & \multicolumn{2}{|c|}{ Shock $4\left(e_{F F R}\right)$} & \multicolumn{2}{|c|}{ Shock $5\left(e_{R H}\right)$} & \multicolumn{2}{|c|}{ Shock $6\left(e_{E X}\right)$} \\
\hline & 1989-99 & $2000-08$ & 1989-99 & $2000-08$ & 1989-99 & $2000-08$ & 1989-99 & $2000-08$ & 1989-99 & $2000-08$ \\
\hline \multicolumn{11}{|c|}{ Variance decomposition of real GDP } \\
\hline 1 & 1.4 & 0.03 & 0 & 0 & 0 & 0 & 0 & 0 & 0 & 0 \\
\hline 2 & 1.46 & 0.94 & 0.03 & 1.2 & 0.05 & 1.26 & 0.01 & 0.22 & 0.98 & 0.8 \\
\hline 3 & 1.81 & 2.26 & 0.09 & 2.09 & 0.06 & 3.11 & 0.03 & 1.36 & 1.26 & 0.68 \\
\hline 5 & 2.63 & 3.06 & 4.97 & 3.38 & 0.05 & 4.96 & 0.41 & 6.64 & 3.14 & 1.04 \\
\hline 8 & 3.52 & 3.81 & 10.75 & 8.92 & 2.82 & 6.65 & 0.89 & 8.56 & 3.2 & 1.45 \\
\hline 12 & 5.62 & 5.42 & 10.49 & 9.73 & 3.15 & 7.9 & 0.98 & 8.64 & 3.34 & 2.03 \\
\hline \multicolumn{11}{|c|}{ Variance decomposition of real investment } \\
\hline 1 & 1.92 & 1.39 & 0 & 0 & 0 & 0 & 0 & 0 & 0 & 0 \\
\hline 2 & 3.27 & 3.87 & 2.88 & 3.13 & 0.28 & 0.62 & 0.11 & 1.33 & 0.16 & 0.45 \\
\hline 3 & 4.68 & 3.32 & 2.9 & 7.9 & 1.22 & 0.42 & 0.76 & 4.24 & 0.28 & 0.43 \\
\hline 5 & 6.51 & 3 & 2.78 & 12.57 & 2.37 & 1.89 & 1.65 & 8.77 & 0.31 & 6.26 \\
\hline 8 & 6.17 & 6.88 & 2.83 & 10.81 & 2.34 & 8.3 & 1.77 & 7.87 & 0.38 & 6.99 \\
\hline 12 & 6.25 & 6.67 & 2.84 & 9.58 & 2.41 & 8.55 & 1.8 & 12.82 & 0.38 & 6.43 \\
\hline \multicolumn{11}{|c|}{ Variance decomposition of $S \& P 500$} \\
\hline 1 & 1.85 & 0.39 & 0.15 & 0.66 & 1.01 & 2.31 & 5.48 & 1.98 & 20.32 & 64.14 \\
\hline 2 & 5.9 & 6.09 & 0.88 & 1.81 & 1.41 & 3.08 & 7.42 & 2.12 & 18.53 & 58.86 \\
\hline 3 & 7.25 & 6.64 & 0.98 & 2.25 & 1.41 & 6.01 & 7.31 & 3.7 & 18.21 & 54.07 \\
\hline 5 & 7.23 & 7.37 & 1.07 & 2.62 & 1.41 & 5.89 & 7.28 & 3.91 & 18.18 & 53.44 \\
\hline 8 & 7.24 & 7.35 & 1.08 & 2.64 & 1.41 & 6 & 7.28 & 3.97 & 18.18 & 53.31 \\
\hline 12 & 7.24 & 7.35 & 1.08 & 2.65 & 1.41 & 6 & 7.28 & 3.97 & 18.18 & 53.3 \\
\hline \multicolumn{11}{|c|}{ Variance decomposition of Home Mortgages } \\
\hline 1 & 8.94 & 0.16 & 0 & 0 & 0 & 0 & 0 & 0 & 0 & 0 \\
\hline 2 & 9.81 & 0.14 & 0.03 & 1.06 & 0.36 & 0.93 & 0.01 & 3.97 & 0.02 & 1.83 \\
\hline 3 & 9.82 & 1.08 & 0.05 & 1.09 & 1.64 & 1.72 & 2.74 & 7.34 & 0.02 & 4.13 \\
\hline 5 & 9.86 & 8.73 & 0.22 & 1.66 & 1.87 & 2.47 & 3 & 11.76 & 0.15 & 8.53 \\
\hline 8 & 9.86 & 7.62 & 0.24 & 11.14 & 1.97 & 6.36 & 3.02 & 10.49 & 0.16 & 11.58 \\
\hline 12 & 9.86 & 7.22 & 0.24 & 11.32 & 1.97 & 7.62 & 3.02 & 11.35 & 0.16 & 16.52 \\
\hline
\end{tabular}

Note: Shock 2 (own shock) is excluded.

Table 3 shows the contemporaneous coefficients in the four structural models. The expected relationship of a negative contemporaneous coefficient between S\&P500 and FFR $\left(b_{24}\right.$ $=-0.510)$ and between S\&P500 and EX $\left(b_{26}=-1.576\right)$ appeared only in the second sub-sample period. For the coefficients estimates of the monetary policy feedback equation (the fourth subequation), the estimated coefficient $b_{41}$ are negative in most cases, while $b_{46}$ is negative in the 
S\&P500 and home mortgages models. The Fed did increase interest rate when faced with an unexpected increase in both OPW and unexpected EX depreciation in the second sub-sample period. However, instead of a positive relationship, the unexpected estimated values of $b_{51}$ and $b_{53}$ are negatively related to the interest rate expectation, implying that investors expected higher interest rate when negative OPW or CPI shocks occurred.

\section{Importance of interest rate expectation on real output and alternative variables}

The forecast error variance decomposition (FEVD) method is used to investigate the contribution of each structural shock in affecting other variables. Table 4 shows that the contribution of FFR (shock 4) and interest rate expectation (shock 5) have significantly increased in the second sub-sample period in most cases, suggesting that their impact on the variance of the real GDP, real investment, and home mortgages in the second sub-sample period was larger than in the first sub-sample period. Hence, when interest rate was low, the FFR and interest rate expectation become more important. In the case of the variance decomposition of real investment, the contribution by CPI (shock 3) and interest rate expectation (shock 5) have outperformed other variables in the second sub-sample period, implying that CPI and interest rate expectation were more important than other variables. The outperformance can be seen from the larger values shown in Table 4. The significance of CPI was probably due to the high OPW in the second sub-sample period. The significance of interest rate expectation suggested that investors could have anticipated interest rate movement, and acted on their investment decisions accordingly.

For the variance decomposition of S\&P500, the contribution of EX (shock 6) is significantly higher than the others, suggesting that the U.S. stock market is heavily influenced by EX. The FEVD analysis demonstrates that the higher contribution on the errors in forecasting real GDP, real investment and home mortgage is due to the variability in the shocks of FFR (shock 4) and interest rate expectation (shock 5) in the second sub-sample period, as seen from the larger values of the estimated coefficients for shocks 4 and 5 when compared to other shocks. This strongly confirmed that investors have fully anticipated the Fed's monetary policy, a result consistent with the Granger-casualty analysis. 


\section{Effectiveness of monetary policy and the impact of interest rate expectation (RH) on output}

If a monetary policy failed to generate an impact expected by the policy makers, one possible reason could probably be due to investors' expectation on interest rate. For example, if investors expected the borrowing cost to remain the same, they might not borrow in the initial stage of a falling interest rate, but should they subsequently anticipate a reversal in interest rate, investor might then choose to borrow before rise in borrowing cost. Investors might show an abrupt change in their expectation on interest rate movement. The impulse response functions can provide a quantitative measure of the dynamic effects of investors' interest rate expectation changes. For the purpose of comparison, we consider an interest rate expectation shock with a structural one standard deviation positive innovation over a horizon of 12 months.

Figure 3 illustrates the impulse response functions of real GDP, real investment, S\&P500 and home mortgages to a positive interest rate expectation shock. This enables us to examine the long term impact of interest rate expectation had on GDP, investment, S\&P500 and home mortgages. A positive interest rate expectation shock represented an increase in the percentage of the investors who expected the interest rate to rise in the next 12 months. Panel A and Panel B in Figure 3 represent the two sub-sample periods, and the upper and lower dashed lines plotted in each chart show the two-standard-error bands generated by Monte Carlo techniques. In response to an interest rate expectation shock, real GDP responded sharply in the second sub-sample period, while S\&P500 responded inversely in both periods. One can conclude that a positive interest rate expectation shock did encourage speculation in the second sub-sample period.

To consider the predictability of investors on the interest rate movement, we examine the dynamic response of interest rate expectation to a positive monetary policy shock, meaning that when investors expected a high interest rate, the Fed would increase the interest rate. Figure 4 shows the estimated impulse response functions of interest rate expectation to a monetary policy shock using the real GDP equation. Figure 4 Panel A shows that a positive monetary policy shock (a rise in interest rate) has generated a negative effect on interest rate expectation until the fourth month and then moved around the zero line after the sixth month. On the contrary, a positive reaction is shown in Panel B, and the highest impact came in the fourth month. This suggested that the positive impact on the interest rate expectation lasted for at least 4 months. One would conclude that the interest rate smoothing policy was well anticipated by investors in the second sub-sample period. 
(I) Real GDP

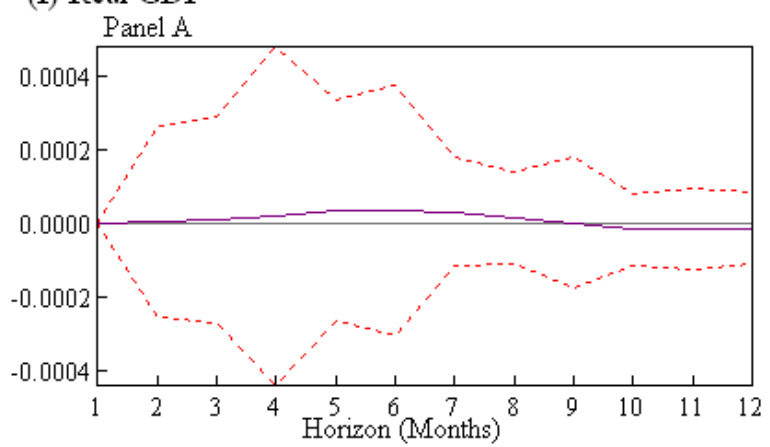

(II) Real investment

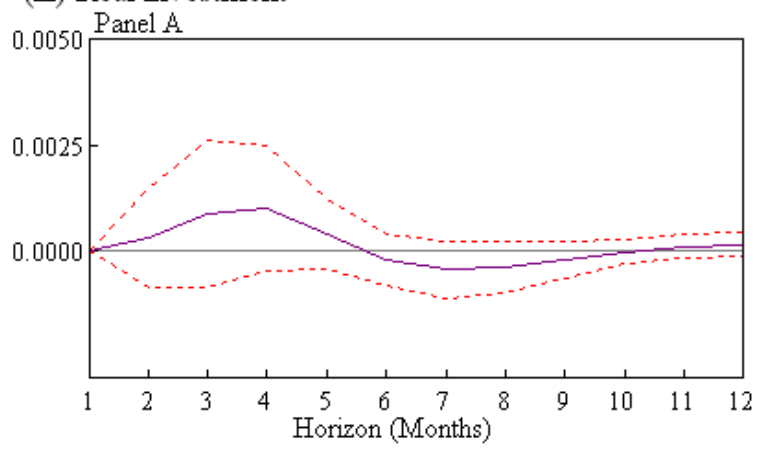

(III) $\mathrm{S} \& \mathrm{P} 500$

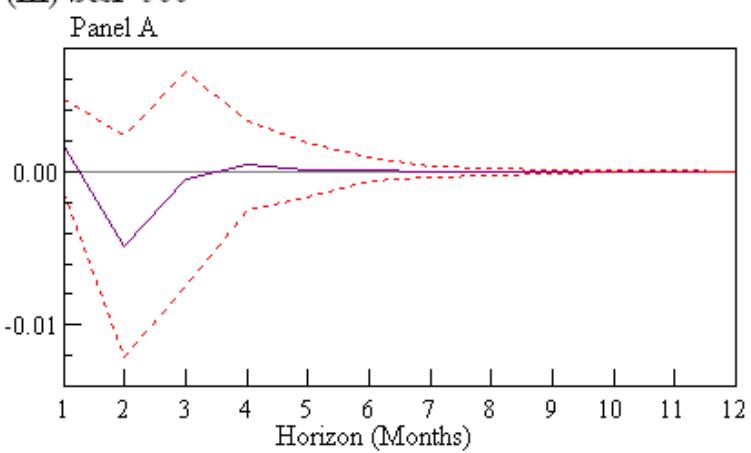

(IV) Home mortgage amount

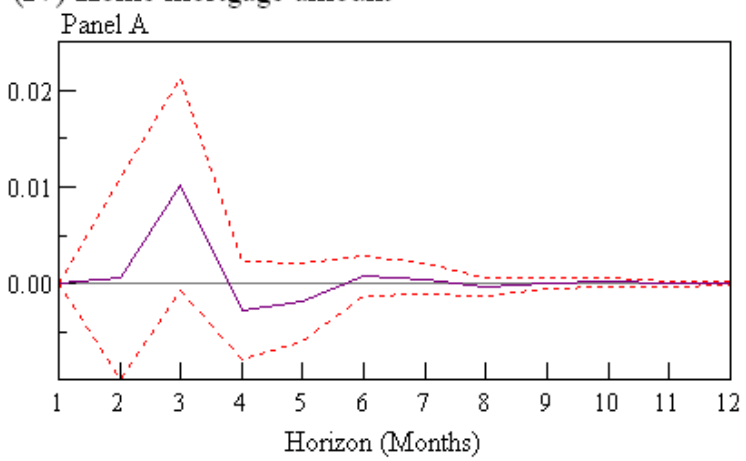

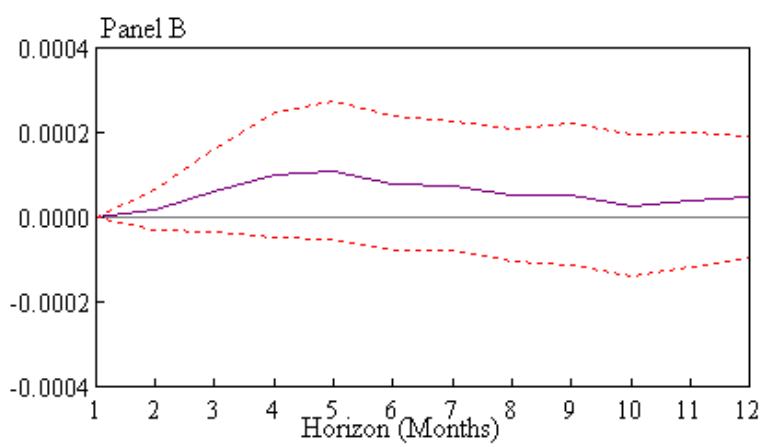
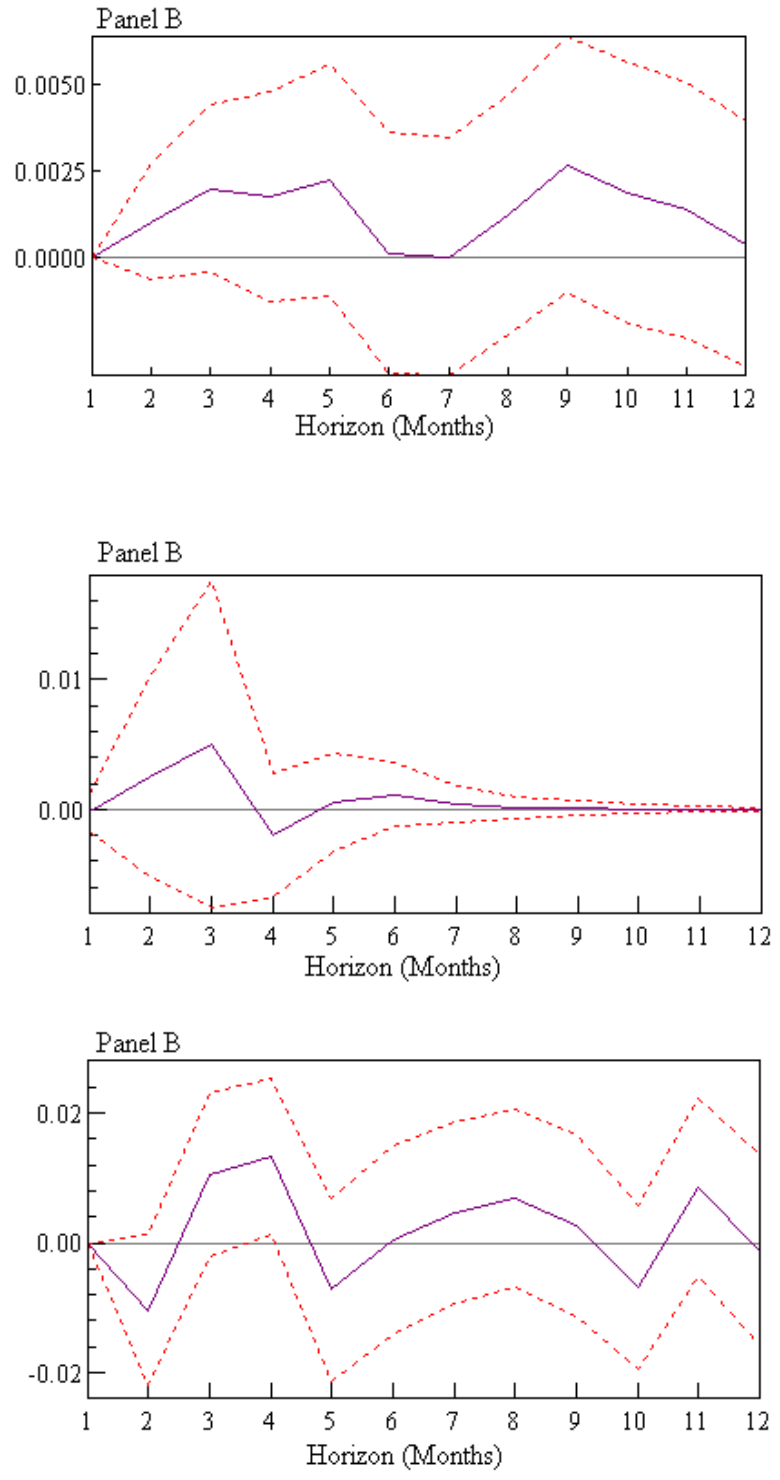

Note: Panel A=1989-1999, Panel B=2000-2008.

Figure 3 Response of Real GDP, Real investment, S\&P500 and Home Mortgages to Interest Rate Expectation $(\mathrm{RH})$ 

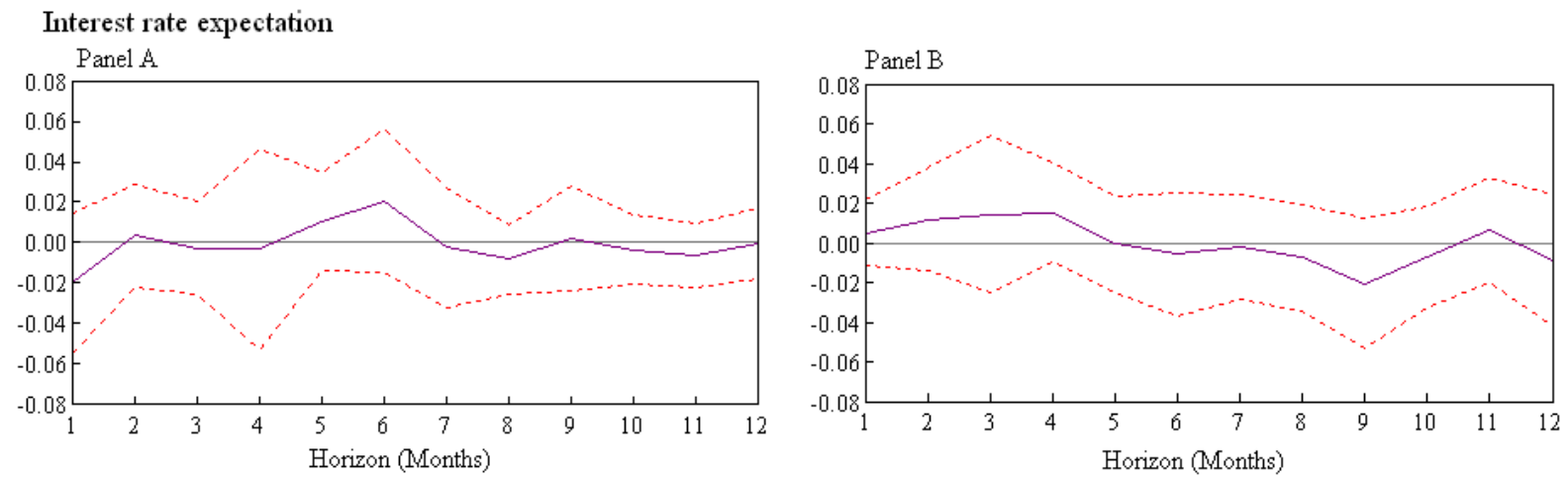

Figure 4 Response of Interest Rate Expectation (RH) to Monetary Policy (FFR) Shock
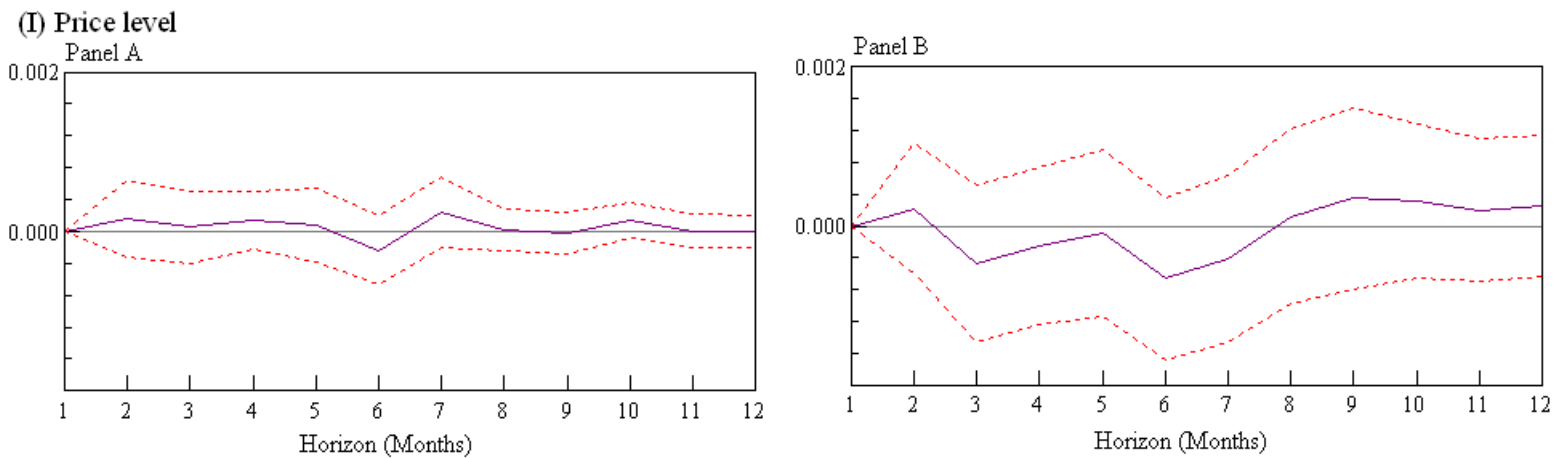

(II) Exchange rate
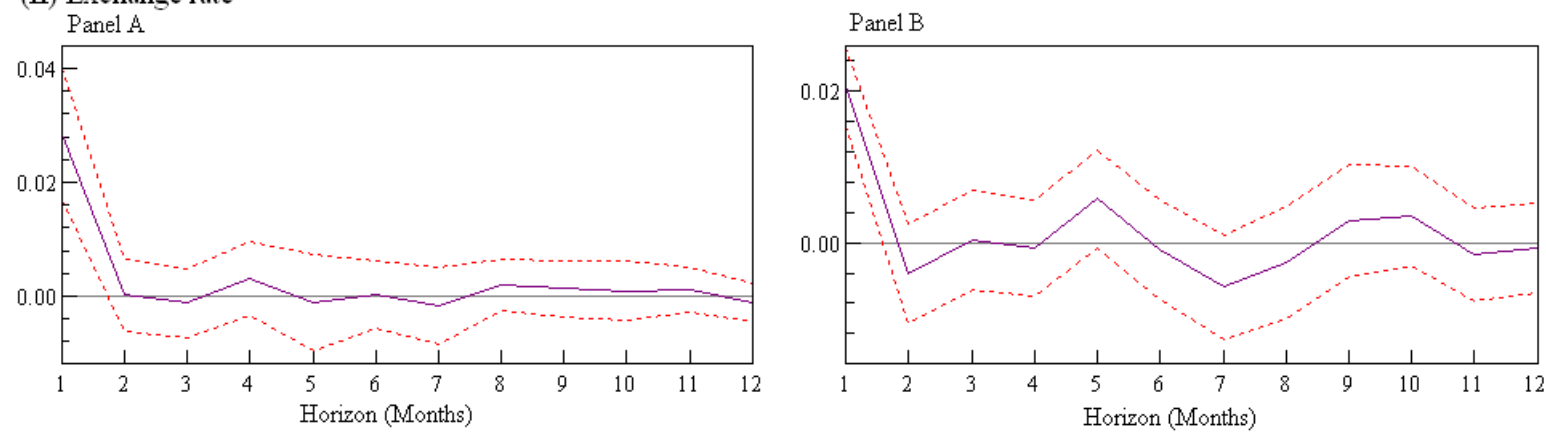

Figure 5 Response of Price Level (CPI) and Exchange Rate (EX) to Monetary Policy (FFR) Shock 


\section{Dynamic responses to monetary policy (FFR) shocks}

It is equally important to illustrate the dynamic responses of economic variables to monetary policy shocks. The reason for the contractionary monetary policy was to control inflation and cool the overheated economy. The response functions of the price level and exchange rate as implied by the real GDP are shown in Figure 5. This shows what response CPI and exchange rate would have when there was an increase in interest rate. In response to a contractionary monetary policy shock, Figure 5 Panel A shows that the price level increased slightly in the first sub-sample period, but dropped below zero after the fifth month, confirming that contractionary monetary shock did not generate a persistent rise in price level. In Figure 5 Panel B, the price level dropped after the second month, which is consistent with expectation. It is obviously that a contractionary monetary policy shock produced a larger effect in lowering inflation rate in the second sub-sample period. In the case of the exchange rate, no significant effect can be found between the two sub-sample periods.

We next examine the dynamic responses of real GDP, real investment, S\&P500 and home mortgages to a contractionary monetary policy shock (rise in interest rate) (Figure 6). The results of Figure 6 Panel A are expected and consistent. A contractionary monetary policy shock is expected to result in a decrease in real GDP, real investment, S\&P500 and home mortgages. In particular, it has a significant negative effect on real investment, S\&P500 and home mortgages in the short run. In Figure 6 Panel B, the responses of real GDP is similar to the first sub-sample period, with a sharply increase in real GDP after the fourth month. In the case of home mortgage, the response in the second sub-sample period is generally larger than that in the first sub-sample period, meaning that an increase in FFR would generate more fluctuation in home mortgage.

Significant difference in the response patterns in real investment and S\&P500 could also be found in the second sub-sample period, implying that stock market behaved differently for the same shock in different periods. A sustained increase in real investment and S\&P500 could be seen in the first few months in the second sub-sample period in response to a contractionary monetary policy, and the rising trends reached the peak at the sixth month and the third month, respectively, before they both declined. Such a result clearly suggested that investment and stock market speculation were encouraged in the short run by a contractionary monetary policy. 

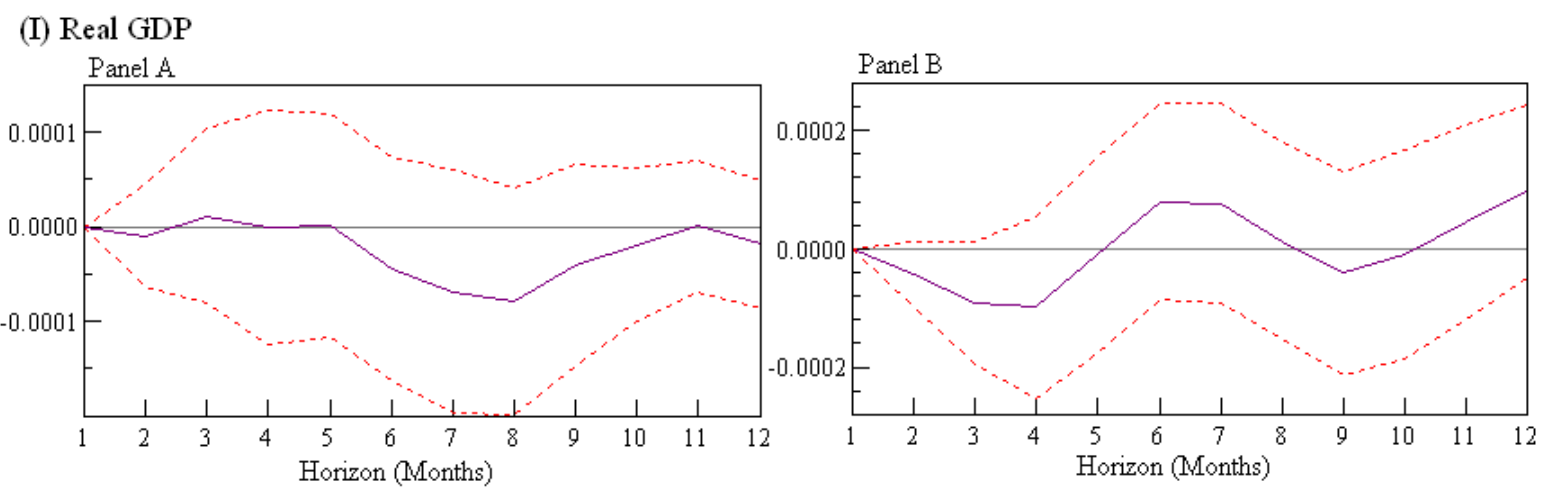

(II) Real investment
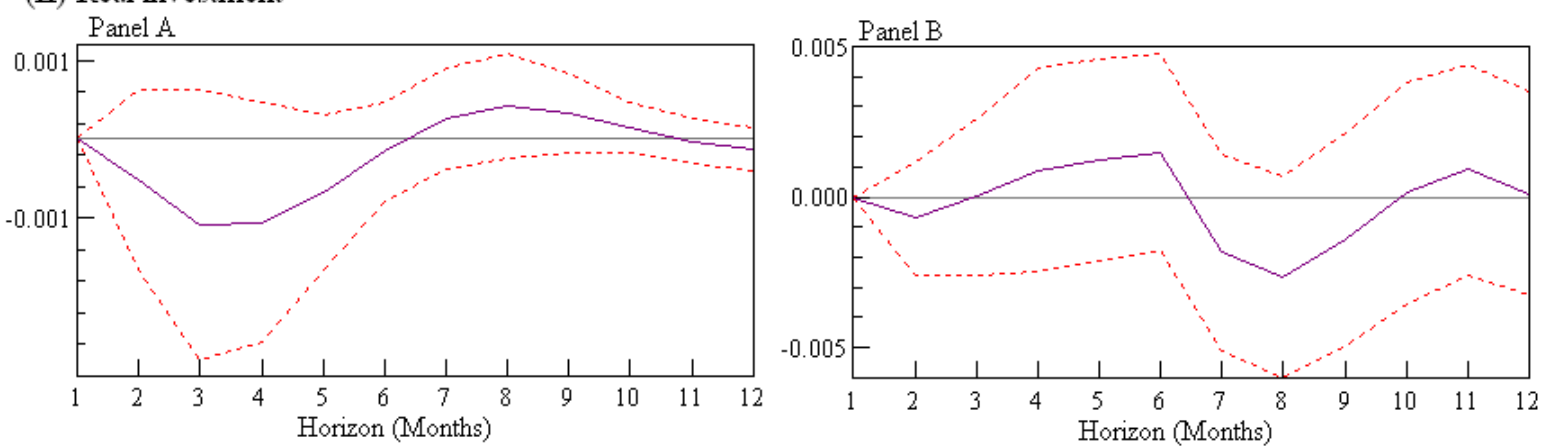

(III) $\mathrm{S} \& \mathrm{P} 500$
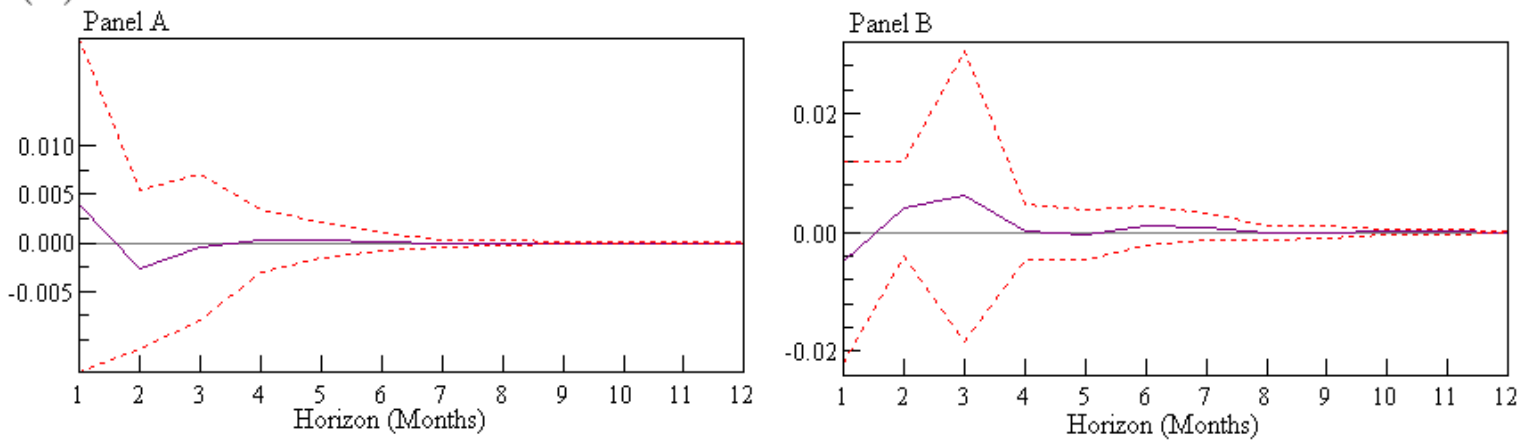

(IV) Home mortgage amount
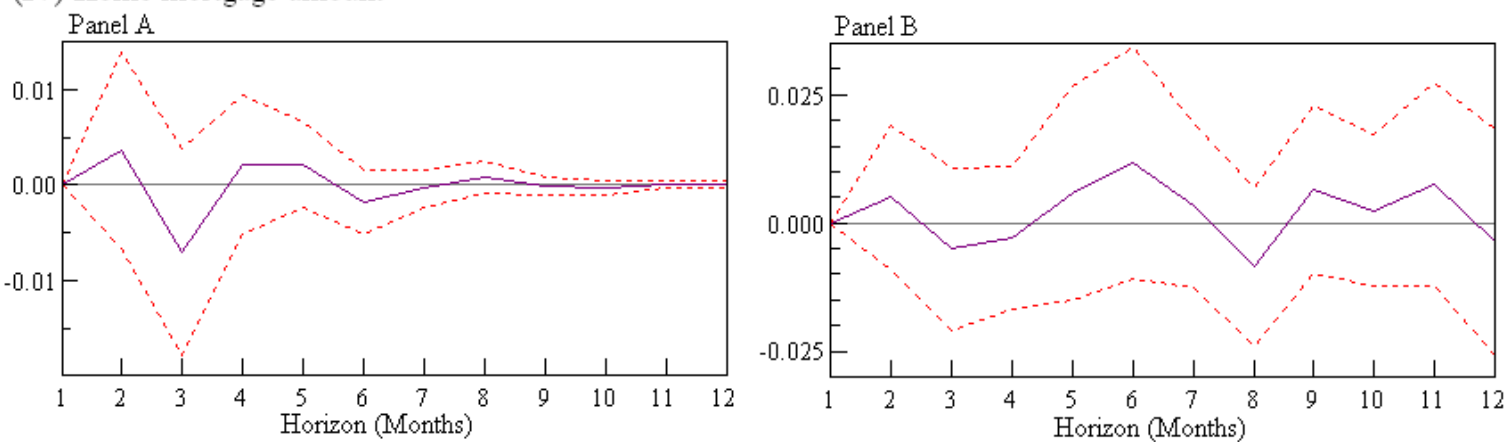

Figure 6 Response of Real GDP, Real Investment, S\&P500 and Home Mortgages to Monetary Policy (FFR) Shock 

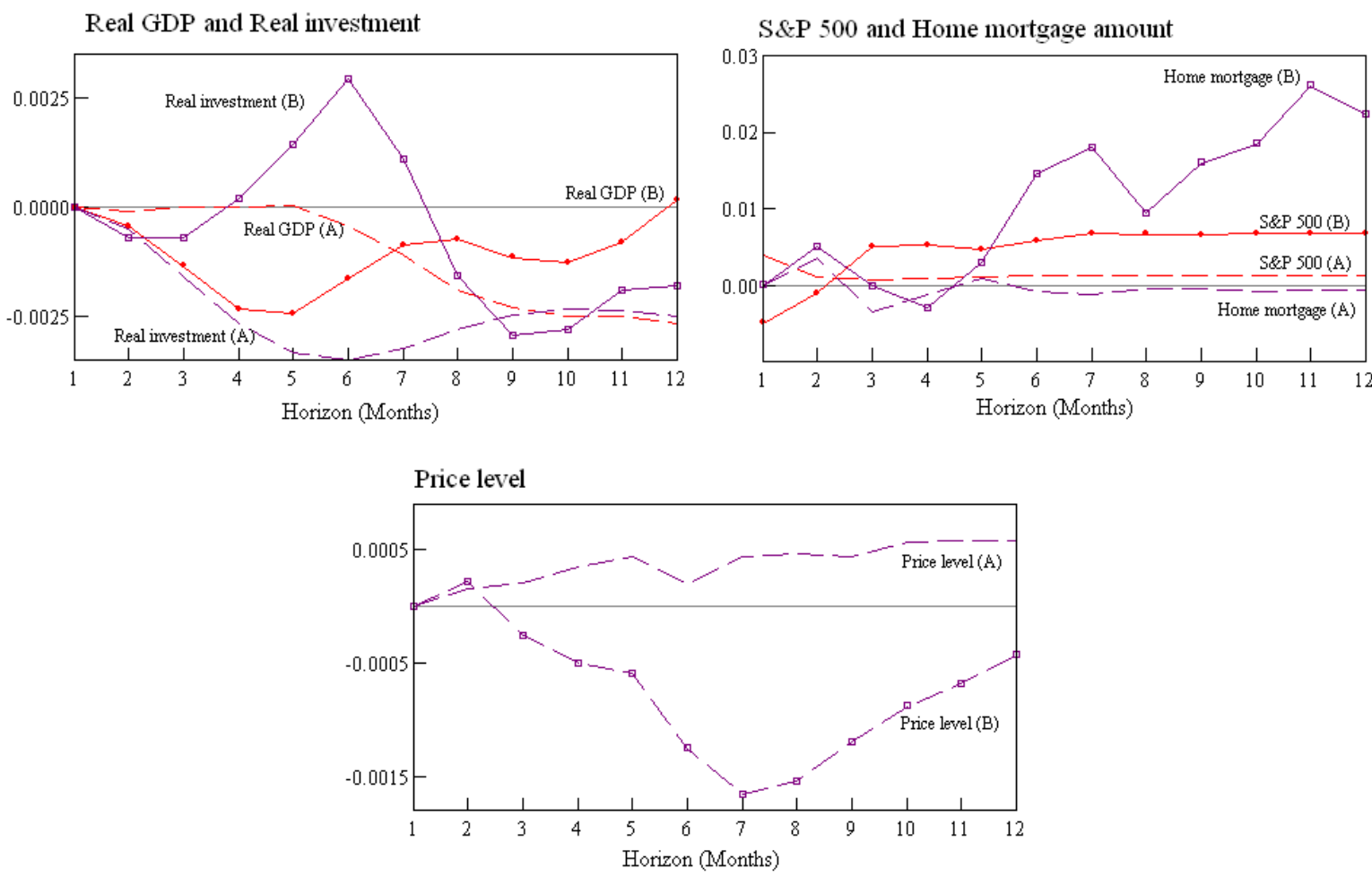

Figure 7 Accumulated Response of Real GDP, Real Investment, S\&P500 and Home Mortgage Amount to Monetary Policy (FFR) Shock

Figure 7 shows the accumulated responses of real GDP, real investment, S\&P500 and home mortgage to a contractionary monetary policy. A lower accumulated response of real GDP to a contractionary policy shock meant that the increase in FFR would lead to a decrease in GDP. In the short run, only real investment was promoted in the second sub-sample period. This meant that the increase in FFR would lead to a decrease in real investment. For the S\&P500, the accumulated response was higher in the second sub-sample period than in the first sub-sample period. Most notably, the accumulated responses of home mortgages between the two subsample periods changed drastically. The contractionary monetary policy has successfully reduced home mortgages in the first sub-sample period, but has greatly stimulated home mortgages in the second sub-sample period, suggesting that there could be other responsible factors. Similarly, the contractionary monetary policy shock has produced a larger effect in lowering inflation rate in the second sub-sample period. It is reasonable to argue that anticipated monetary policy was the crucial reason in generating the sub-prime mortgage crisis that started in late 2007 and caused 
further deterioration of the U.S. economy. In short, the increase in interest rate had led to a decrease in CPI and an increase in home mortgage that gave rise to the sub-prime mortgage crisis.

\section{Conclusion}

Interest rate expectation plays an important role in the U.S. economy. During 2000-2008, a positive interest rate expectation shock did not only encourage investment but speculation in the financial markets. Empirical evidence shows that a contractionary monetary policy has overheated real investment though it lowered the price level and output. The response of economic variables to a monetary policy shock may not follow the conventional wisdom when the policy is fully anticipated.

This empirical analysis relates the discussion back to the basics of monetary economics, and in particular, the problem of monetary policy uncertainties (Friedman, 1968; Poole, 1970; Romer and Romer, 1989; Brainard, 1967). Similar to Friedman's $(1948,1960)$ idea of a constant money supply, it probably would be appropriate for policy makers to pursue an "interest rate anchor" such that the adoption of a steady interest rate allows the business cycle to develop, evolve around or respond to the interest rate rather than changing the interest rate ostensibly to suit the business cycle.

The conjecture of a "low interest rate trap" highlighted a monetary phenomenon that could give rise to unintended economic consequences. It encouraged low-return investment and speculation which were unmatched with economic growth. Investors with full anticipation on the movement of the interest rate could result in a business cycle that built around the policy. It is preferable to have an effective and steady interest rate anchor that allows the business cycle to run its own course and be regulated by private economic activities. The government at most needs to fine tune the "interest rate anchor" should the business cycle deviates from normal. 


\section{References}

Barro, R. J., 1976. Rational expectations and the role of monetary policy. Journal of Monetary Economics 2, January, 1-32.

Barro, R. J., Gordon, D. B., 1983. Rules, discretion and reputation in a model of monetary policy. Journal of Monetary Economics 12, 101-22.

Bernanke, B. S., Blinder, Alan S. 1992. The federal funds rate and the channels of monetary transmission. American Economic Review 82 (4) September, 901-921.

Bernanke, B. S., Mishkin, F. S., 1997. Inflation targeting: a new framework for monetary policy?. Journal of Economic Perspectives 11, Spring, 97-116.

Blinder, Alan S., Reis, Ricardo, 2005. Understanding the Greenspan Standard. Economic Symposium on "The Greenspan Era: Lessons for the Future", Federal Reserve Bank of Kansas City, Jackson Hole, WY.

Brainard, W., 1967. Uncertainty and the effectiveness of policy. American Economic Review 57 (2), 411-425.

Bryant, R., Hooper, P., Mann, C., 1993. Evaluating Policy Regimes: New Research in Empirical Macroeconomics. Washington, D.C.: Brookings Institution.

Bullard, James, Mitra, Kaushik, 2006. Determinacy, learnability and monetary policy inertia. Journal of Money, Credit and Banking 39 (5), 1177-1212.

Caplin, A., Leahy, J., 1996. Monetary policy as a process of search. American Economic Review 86 (4), 689-702.

Cecchetti, S., 1996. Practical issues in monetary policy targeting. Federal Reserve Bank of Cleveland Economic Review 32 (1), 2-15.

Christiano, L. J., Eichenbaum, M., Evans, C., 1996. Identification and the effects of monetary policy shocks In: Blejer, M. I., Eckstein, Z., Hercowitz, Z., Leiderman, L. (Eds.), Financial Factors in Economic Stabilization and Growth, New York: Cambridge University Press, 36-74.

Ehrmann, M., Fratzcher, M., 2004. Equal Size, Equal Role? Interest Rate Interdependence between the Euro Area and the United States. European Central Bank Working Paper Series 342.

Financial Services Authority, 2009. The Turner Review: A Regulatory Response to the Global Banking Crisis, London, March.

Fischer, S., 1990. Rules versus discretion. In: Friedman, B. M., Hahn, F. H., (eds.). Handbook of Monetary Economics. Amsterdam: North-Holland, 1155-1184. 
French, Kenneth R., Baily, Martin N., Campbell, John Y., Cochrane, John H., Diamond, Douglas W., Duffie, Darrell, Kashyap, Anil K., Mishkin, Frederic S., Rajan, Raghuram G., Scharfstein, David S., Shiller, Robert J., Shin, Hyun Song, Slaughter, Matthew J., Stein, Jeremy C., Stulz, René M., 2010, The Squam Lake Report: Fixing the Financial System, Princeton: Princeton University Press.

Friedman, Milton, 1948. A monetary and fiscal framework for economic stability. American Economic Review 38, 245-64.

Friedman, Milton, 1960. A Program for Monetary Stability. New York: Fordham.

Friedman, Milton, 1968. The role of monetary policy. American Economic Review 58, 1-17.

Goodfriend, Marvin, 2005. Inflation Targeting for the United States?. In: Bernanke, B. S., Woodford, Michael, (eds.). The Inflation Targeting Debate. Cambridge, Mass.: NBER, 311-37.

Goodhart, C., 1996. Why Do the Monetary Authorities Smooth Interest Rates? LSE Financial Markets Group Special Paper No. 81.

International Monetary Fund, 2009, Global Financial Stability Report: Responding to the Financial Crisis and Measuring Systemic Risks, April, Washington DC.

Kim, Soyoung, Roubini, Nouriel, 2000. Exchange rate anomalies in the industrial countries: a solution with a structural VAR approach. Journal of Monetary Economics 45 (3), 561-586.

Kydland, Finn, Prescott, Edward C., 1977. Rules rather than discretion: the inconsistency of optimal plans. Journal of Political Economy 85 (3) June, 473-91.

Lucas, Robert E. Jr., 1981. Studies in Business-Cycle Theory. Cambridge, Mass.: MIT Press.

Mankiw, G. N., 2002. U.S. monetary policy during the 1990s. In Frankel, F., Orszag, P., (eds.), American Economic Policy in the 1990s. Cambridge, Mass.: MIT Press. 18-60.

McCallum, B., 1988. Robustness properties of a rule for monetary policy. Carnegie Rochester Conference Series on Public Policy 29, 173-203.

Mehra, Yash P., Minton, Brian D., 2007. A Taylor rule and the Greenspan era. Economic Quarterly 93 (3), 229-250.

Miller, M., Weller, P., Zhang, L., 2002. Moral hazard and the US stock market: analyzing the 'Greenspan Put'. Economic Journal 112 (478) March, C171-186.

Modigliani, Franco, 1977. The monetarist controversy or should we forsake stabilization policies? American Economic Review 67 March, 1-19.

Poole, William, 1970. Optimal choice of monetary policy instruments in a simple stochastic 
macro model. Quarterly Journal of Economics 84 (2) May, 197-216.

Romer, Christina D., Romer, David H., 1989. Does monetary policy matter? A new test in the spirit of Friedman and Schwartz. In: Blanchard, O. J., Fischer, S., (eds.), NBER Macroeconomics Annual. Cambridge, Mass: MIT Press, 121-169.

Sargent, T., Wallace, N., 1975. 'Rational' expectations, the optimal monetary instrument, and the optimal money supply rule. Journal of Political Economy April, 241-54.

Schwartz, A. J., 2009, Origins of the financial market crisis of 2008, Cato Journal 29 (1), 19-23.

Sims, C. A., 1992. Interpreting the macroeconomic time series facts: the effects of monetary policy. European Economic Review 36 (5), 975-1011.

Sims, C. A., Leeper, E., Zha, T. 1996. What Does Monetary Policy Do? Brookings Papers on Economic Activity 2, 1-63.

Sims, C. A., Zha, T., 2006. Does Monetary Policy Generate Recessions? Macroeconomic Dynamics, 10 (2) April, 231-272..

Solnik, B., 1987. Using financial prices to test exchange rate models: a note. Journal of Finance 42 (1), 141-149.

Taylor, John B., 1993. Discretion versus policy rules in practice. Carnegie-Rochester Conference Series on Public Policy 39, 195-214.

Taylor, John B., 2009, Getting Off Track: How Government Actions and Interventions Caused, Prolonged, and Worsened the Financial Crisis, Stanford: Hoover Institution Press.

Taylor, John B., Williams, John C., 2009. A Black Swan in the Money Market. NBER Working Paper 13943, Cambridge, Mass., April.

Wong, K. T., Li, K.-W., 2010. Comparing the performance of relative stock return differential and real exchange rate in two financial crises. Applied Financial Economics 20 (1/2), 137-150.

Woodford, Michael, 2001. The Taylor rule and optimal monetary policy. American Economic Review 91 (2), 232-237.

Yellen, Janet, 2004. Innovations and issues in monetary policy. American Economic Review Paper and Proceedings 94, 45-47. 